\title{
Phenotypic stability of hybrids of Gália melon in Rio Grande do Norte state, Brazil
}

\author{
GLAUBER H.S. NUNES ${ }^{1}$, HAROLDO SANTOS JÚNIOR ${ }^{1}$, LEILSON C. GRANGEIRO ${ }^{1}$, \\ FRANCISCO BEZERRA NETO ${ }^{1}$, CARLOS T.S. DIAS ${ }^{2}$ and MARA S.M. DANTAS ${ }^{1}$ \\ ${ }^{1}$ Departamento de Ciências Vegetais/UFERSA, Caixa Postal 137, 59625-900 Mossoró, RN, Brasil \\ ${ }^{2}$ Departamento de Ciências Exatas/LCE/ESALQ/USP, Caixa Postal 09, 13418-900 Piracicaba, SP, Brasil \\ Manuscript received on October 19, 2009; accepted for publication on December 1, 2010
}

\begin{abstract}
The objectives of this study were to determine the importance of simple and complex components of the interaction genotype $\times$ environment and to evaluate the adaptability and stability of Gália melon hybrids. Nine hybrids were tested in twelve environments of Rio Grande Norte State from 2000 to 2001 . The experiments were carried out in a randomized complete block design with three replications. The statistical methods of Toler and Burrows, Wricke and AMMI (Additive Main effect and Multiplicative Interaction) were used to study the adaptability and stability. The complex component is responsible for most of the genotype $\times$ environment interaction for the yield and content of solids soluble of fruits. The environments associated with Mossoró and Assu municipalities are the most suitable to evaluate melon hybrids in the state. The hybrid DRG 1537 was the most likely to be grown in the Agro-industrial Complex Mossoró-Assu due to its stability, high productivity and high content of soluble solids.
\end{abstract}

Key words: Cucumis melo, genotype $\times$ environment interaction, AMMI analysis, non-linear grouping protocol, hybrids.

\section{INTRODUCTION}

The Mossoró-Assu Agro-industrial Complex situated in Rio Grande do Norte State is the Brazilian leading producer and exporter of melons (FNP 2008). The melon crop also plays a major social role by employing between 15,000 and 20,000 people. Climatic conditions such as intense sunlight - about 3,000 hour.year ${ }^{-1}$ and low rainfall indicators - excepting the January-May period once it is the "rainy season" - in association with the use of high technology by the production sector, place the state in a very important position in the national agribusiness (Nunes et al. 2005).

Most of the melon fruits that grow in the Mossoró-Assu Agricultural Complex belong to the inodorus group. Nonetheless, in order to provide the market

Correspondence to: Francisco Bezerra Neto

E-mail: bezerra@ufersa.edu.br with a wider variety of the product, many commercial growers have been cultivating the Gália-type melon. This type of melon is a commercial class developed in the seventies at the Newe Ya'ar Research Center of Israel's Agricultural Research Organization. The characteristics of this melon type are: round-shaped fruits of yellow color, yellow-green flesh, smooth netting, aroma, weight ranging from 1,00 to $1,50 \mathrm{~g}$, soluble solids content between 13 and $15 \%$, yield around 35 to 50 t.ha $^{-1}$, and post-harvest life between 14 and 20 days (Karchi 2000). About $6.0 \%$ of the melon exported through the port of Natal belongs to the Gália type (Sales Júnior et al. 2006). The growers' intention is to increase the area under cultivation with this type of melon due to its high value at the international market.

To attend the production sector demand, seed companies have been developing cultivars of the Gália 
type by introducing new hybrids on a yearly basis. However, to choose any of these hybrids that grow in Europe and America - without any prior evaluation of the yield and quality of their fruits - can jeopardize the trade between Brazil and the international market once European consumers are very concerned about the quality of the fruits they eat (Nunes et al. 2004).

Due to distinct environmental conditions in which melon hybrids are grown in Rio Grande do Norte State, a significant genotype $\times$ environment interaction is expected to occur, and this interaction plays an important role on phenotypic expression. The interaction genotype $x$ environment derives from the typical performance of the genotypes in different environments, thus indicating that the best cultivars in one environment may not perform likewise in another (Rezende 2002).

When an interaction is noticed, it is vital to try to reduce its effect. One of the options to do this is to use genotypes with phenotypic stability. To identify stable hybrids, various methods have been suggested, which differ from one another in their concepts of stability, imposed restrictions and biometrical procedures for estimation (Cruz and Regazzi 1994, Kang 1998).

The most commonly used methods are those based on linear regression with just one (Finlay and Wilkinson 1963, Eberhart and Russel 1966) or two line segments (Verma et al. 1978, Silva and Barreto 1985, Cruz et al. 1989). Toler and Burrows (1998) suggested a non-linear regression model for the parameters, which overcomes the problems related to the estimation of the environmental ratio and shows the testing of more rigorous hypotheses for the patterns of response. It allows the classification of hybrids under various groups, thus making it a promising method for the study of adaptability and stability. This method has been used to study crops such as beans (Rosse and Vencovsky 2000), sugarcane (Rosse et al. 2002), eucalyptus (Nunes et al. 2002), melon (Nunes et al. 2006) and soybean (Morais et al. 2008).

Many authors have used multivariate techniques such as the AMMI (Additive Main effects and Multiplicative Interaction) analysis (Gabriel 1971), one of the most used models of this kind (Oliveira et al. 2003). This method combines statistical techniques such as analysis of variance and analysis of principal components to ad- just the main effects (genotypes and environments) and the effects of the genotype $\times$ environment interaction, respectively (Gollob 1968, Duarte and Vencovsky 1999, Fan et al. 2007). The AMMI model can help not only to identify superior genotypes widely adapted, but also to carry out the so-called agricultural zoning for the purposes of regionalized recommendation and selection of evaluation locations (Gauch Jr 2006).

Thus, the objectives of this study were to determine the importance of simple and complex components of the interaction genotype $\times$ environment and to evaluate the adaptability and stability of Gália melon hybrids in Rio Grande do Norte State, Brazil.

\section{MATERIALS AND METHODS}

The experiments were conducted in twelve environments in the municipalities of Mossoró, Baraúna, Assu and Alto do Rodrigues at the Mossoró-Assu Agro-industrial Complex. The experiments were carried out from August to October 2000, 2001 and 2002 (Table I) in a randomized complete block design with three replications. Nine simple, andromonoic hybrids of melon type Gália named Arava, DRG 1531, DRG 1537, Galileu, GPS 400, Num 1502, Solar King, Solarbel and Supra were evaluated.

The plots were double row, 5.0 meters long and 2.0 meters wide. Plants were placed $0.5 \mathrm{~m}$ apart, one plant per hole. Each plot had 20 plants. Therefore, the harvest area consisted of 16 central plants in the rows. A drip system was used to irrigate and fertilize the crop. The drip tubes with emitters were placed $0.5 \mathrm{~m}$ apart, and flow rate of $300 \mathrm{~m}^{3} \mathrm{ha}^{-1}$ were placed $2.0 \mathrm{~m}$ apart between rows. The plants were $5.0 \mathrm{~cm}$ far from the drip tubes. The irrigation was made two times daily. The information on fertilizers and other cultural practices is shown in Table II.

The traits evaluated were: yield ( $\left.\mathrm{t} \mathrm{ha}^{-1}\right)$ and soluble solids content (\%). Both traits have been pointed out by growers of the Mossoró-Assu Agro-industrial Complex as the most important ones. The yield was obtained through the sum of the weight of all fruits harvested per plot. The fruits were individually weighed on an electronic scale (from 0 to $25 \mathrm{~kg}$ ). The results were expressed in $\mathrm{t} \mathrm{ha}^{-1}$. The total soluble solids content was determined by refractometer using filtered juice from 
TABLE I

Environments, sites, years, geographic coordinates, height, rainfall, relative humidity (RH), mean maximum temperature $\left(T_{\max }\right)$ and mean minimum temperature $\left(T_{\min }\right)$ over the period of conducting the experiments in each environment for evaluation.

\begin{tabular}{c|c|c|c|c|c|c|c|c}
\hline Environments & Locations & Years & $\begin{array}{c}\text { Geographical } \\
\text { coordinates }\end{array}$ & $\begin{array}{c}\text { Height } \\
(\mathrm{m})\end{array}$ & $\begin{array}{c}\text { Rainfall } \\
(\mathrm{mm})\end{array}$ & $\begin{array}{c}\mathrm{RH} \\
(\%)\end{array}$ & $\begin{array}{c}\mathrm{T}_{\max } \\
\left({ }^{\circ} \mathrm{C}\right)\end{array}$ & $\begin{array}{c}\mathrm{T}_{\min } \\
\left({ }^{\circ} \mathrm{C}\right)\end{array}$ \\
\hline MO-00 & Mossoró & 2000 & $5^{\circ} 11^{\prime} \mathrm{S}$ & 18 & 60.0 & 60.2 & 32.3 & 27.66 \\
MO-01 & & 2001 & $37^{\circ} 21^{\prime} \mathrm{W}$ & & 0.0 & 63.4 & 31.2 & 28.37 \\
MO-02 & & 2002 & & & 0.0 & 63.4 & 30.2 & 28.27 \\
\hline BA-00 & Baraúna & 2000 & $5^{\circ} 05^{\prime} \mathrm{S}$ & 94 & 39.8 & 61.2 & 34.2 & 27.64 \\
BA-01 & & 2001 & $37^{\circ} 38^{\prime} \mathrm{W}$ & & 2.0 & 64.2 & 29.8 & 27.27 \\
BA-02 & & 2002 & & & 41.2 & 63.5 & 31.2 & 28.17 \\
\hline AS-00 & Assu & 2000 & $5^{\circ} 34^{\prime} \mathrm{S}$ & 27 & 85.8 & 64.2 & 30.4 & 28.66 \\
AS-01 & & 2001 & $36^{\circ} 54^{\prime} \mathrm{W}$ & & 7.0 & 62.3 & 30.8 & 28.88 \\
AS-02 & & 2002 & & & 2.1 & 64.3 & 30.5 & 28.17 \\
\hline AR-00 & Alto & 2000 & $5^{\circ} 20^{\prime} \mathrm{S}$ & 30 & 59.7 & 62.5 & 31.7 & 28.66 \\
AR-01 & Rodrigues & 2001 & $36^{\circ} 50^{\prime} \mathrm{W}$ & & 0.0 & 53.8 & 33.2 & 29.01 \\
AR-02 & & 2002 & & & 0.0 & 54.6 & 34.1 & 28.54 \\
\hline
\end{tabular}

melon flesh blended in a kitchen blender. The reading was taken on a digital refractometer with automatic temperature correction (scale from 0 to $32 \%$ ).

An analysis of variance was done for each environment, and then a joint analysis was performed for all of them together. To decompose the genotype $x$ environment interaction into simple and complex components, analyses of variance were performed at every two environments, totalizing 66 analyses of variances. The method proposed by Cruz and Castoldi (1991) was used to estimate the simple and complex parts. The decomposition analysis of the hybrid $\times$ environment interaction was carried out using the GENES software (Cruz 2001).

The estimation of adaptability and stability parameters was performed using the methods proposed by Toler and Burrows (1998) and Wricke (1965), and the AMMI analysis (Gollob 1968, Gabriel 1971).

Two models are considered in Toler and Burrows's method (1998). Model 1 predicts a linear behavior of the hybrids when facing environmental variations, whereas model 2 is bisegmented. The least squares method under non-linear models with the modified Gauss-Newton algorithm was used.

After the adjustment of models 1 and 2, the criterion for classifying the hybrids was used according to the pattern of response in relation to the environments, which are as follows: Group A: Hypothesis $\beta_{1}=\beta_{2}$ is rejected and $\beta 1<1<\beta_{2}$ accepted; Group B: Hypothesis $\beta_{1}=\beta_{2}$ is accepted and $\mathrm{H}(\beta=1)$ rejected, $\beta>1$ being the common; Group C: Hypothesis $\beta_{1}=$ $\beta_{2}$ is accepted and $\mathrm{H}(\beta=1)$ accepted; Group D: Hypothesis $\beta_{1}=\beta_{2}$ is accepted, and $\mathrm{H}(\beta=1)$ rejected; $\beta<1$ being the common; and Group E: Hypothesis $\beta_{1}=\beta_{2}$ is rejected and $\beta_{1}>1>\beta_{2}$ accepted.

The practical meanings of the five groups are as follows: A: convex response and double desirable; B: simple linear response and desirable only in high quality environments; C: simple linear response, not deviating from the average response; D: simple linear response and desirable only in poor quality environments; and $\mathrm{E}$ : concave response and double undesirable.

The calculation of $\mathrm{R}^{2}$ corresponded to the square of the correlation coefficient estimated from the values observed for the hybrids and the values estimated through the non-linear model for stability (Rosse and Vencovsky 2000).

The method proposed by Wricke estimates the stability parameter $W_{i}$ called ecovalence. The estimator of $W_{i}$ is expressed as follows:

$$
\hat{W}_{i}=\sum_{j=1}^{k}\left(Y_{i j}-\overline{Y_{i .}}-\overline{Y_{. j}}+\overline{Y_{. .}}\right)^{2},
$$

where: $\hat{W}_{i}=$ ecovalence estimator; $Y_{i j}=$ average of 
TABLE II

Environments, sowing, sowing fertilizing, side dressing, number of daily irrigations and number of weedings in the experiments in each evaluated environment.

\begin{tabular}{|c|c|c|c|c|c|}
\hline Environments & Sowing & $\begin{array}{l}\text { Sowing fertilizing } \\
\text { (ha) }\end{array}$ & $\begin{array}{l}\text { Side dressing } \\
\text { (ha) }\end{array}$ & $\begin{array}{l}\text { Number of } \\
\text { daily } \\
\text { irrigations }\end{array}$ & $\begin{array}{l}\text { Number of } \\
\text { weedings }\end{array}$ \\
\hline MO-00 & TS1 & $\begin{array}{l}12 \mathrm{t} \text { cattle manure, } \\
400 \mathrm{~kg} \mathrm{KCl}, \\
120 \mathrm{~kg} \text { urea, } \\
300 \mathrm{~kg} \mathrm{~K}_{2} \mathrm{O} \text { and } \\
90 \mathrm{~kg} \mathrm{P}_{2} \mathrm{O}_{5}\end{array}$ & $\begin{array}{l}100 \mathrm{~kg} \text { urea, } \\
370 \mathrm{~kg} \mathrm{~K} 2 \mathrm{O} \text { and } \\
70 \mathrm{~kg} \mathrm{P}_{2} \mathrm{O}_{5}\end{array}$ & 2 & 2 \\
\hline MO-01 & TS & $\begin{array}{l}12 \mathrm{t} \text { cattle manure, } \\
450 \mathrm{~kg} \mathrm{KCl}, \\
120 \mathrm{~kg} \text { urea, } \\
300 \mathrm{~kg} \mathrm{~K}_{2} \mathrm{O} \text { and } \\
90 \mathrm{~kg} \mathrm{P}_{2} \mathrm{O}_{5}\end{array}$ & $\begin{array}{l}100 \mathrm{~kg} \text { urea, } \\
370 \mathrm{~kg} \mathrm{~K} 2 \mathrm{O} \text { and } \\
70 \mathrm{~kg} \mathrm{P}_{2} \mathrm{O}_{5}\end{array}$ & 2 & 2 \\
\hline MO-02 & $\mathrm{TS}$ & $\begin{array}{l}12 \mathrm{t} \text { cattle manure, } \\
400 \mathrm{~kg} \mathrm{KCl}, \\
120 \mathrm{~kg} \text { urea, } \\
300 \mathrm{~kg} \mathrm{~K}_{2} \mathrm{O} \text { and } \\
90 \mathrm{~kg} \mathrm{P}_{2} \mathrm{O}_{5}\end{array}$ & $\begin{array}{l}100 \mathrm{~kg} \text { urea, } \\
370 \mathrm{~kg} \mathrm{~K} 2 \mathrm{O} \text { and } \\
70 \mathrm{~kg} \mathrm{P}_{2} \mathrm{O}_{5}\end{array}$ & 2 & 2 \\
\hline BA-00 & $\mathrm{TF}$ & $\begin{array}{l}8 \mathrm{t} \text { cattle manure, } \\
500 \mathrm{~kg} \mathrm{KCl}, \\
90 \mathrm{~kg} \text { urea, } \\
250 \mathrm{~kg} \mathrm{~K} 2 \mathrm{O} \text { and } \\
120 \mathrm{~kg} \\
\mathrm{P}_{2} \mathrm{O}_{5}\end{array}$ & $\begin{array}{l}100 \mathrm{~kg} \text { urea and } \\
370 \mathrm{~kg} \mathrm{~K}_{2} \mathrm{O}\end{array}$ & 2 & 2 \\
\hline BA-01 & $\mathrm{TS}$ & $\begin{array}{l}6 \text { t cattle manure, } \\
560 \mathrm{~kg} \mathrm{KCl}, \\
90 \mathrm{~kg} \text { urea, } \\
250 \mathrm{~kg} \mathrm{~K} 2 \mathrm{O} \text { and } \\
120 \mathrm{~kg} \mathrm{P}_{2} \mathrm{O}_{5}\end{array}$ & $\begin{array}{l}100 \mathrm{~kg} \text { urea and } \\
380 \mathrm{~kg} \mathrm{~K}_{2} \mathrm{O}\end{array}$ & 2 & 3 \\
\hline BA-02 & $\mathrm{TF}$ & $\begin{array}{l}8 \mathrm{t} \text { cattle manure, } \\
500 \mathrm{~kg} \mathrm{KCl}, \\
90 \mathrm{~kg} \text { urea, } \\
250 \mathrm{~kg} \mathrm{~K} 2 \mathrm{O} \text { and } \\
120 \mathrm{~kg} \mathrm{P}_{2} \mathrm{O}_{5}\end{array}$ & $\begin{array}{l}100 \mathrm{~kg} \text { urea and } \\
380 \mathrm{~kg} \mathrm{~K} \mathrm{~K}_{2} \mathrm{O}\end{array}$ & 2 & 2 \\
\hline AS-00 & $\mathrm{TF}$ & $\begin{array}{l}10 \text { t cattle manure, } \\
450 \mathrm{~kg} \mathrm{KCl}, \\
120 \mathrm{~kg} \text { urea, } \\
450 \mathrm{~kg} \mathrm{~K}_{2} \mathrm{O} \text {, } \\
120 \mathrm{~kg} \mathrm{P}_{2} \mathrm{O}_{5} \text { and } \\
100 \mathrm{~kg} \mathrm{Ca}\end{array}$ & $\begin{array}{l}100 \mathrm{~kg} \text { urea and } \\
380 \mathrm{~kg} \mathrm{~K} \mathrm{~K}_{2} \mathrm{O}\end{array}$ & 2 & 2 \\
\hline AS-01 & $\mathrm{TF}$ & $\begin{array}{l}8 \mathrm{t} \text { cattle manure, } \\
450 \mathrm{~kg} \mathrm{KCl}, \\
120 \mathrm{~kg} \text { urea, } \\
450 \mathrm{~kg} \mathrm{~K} 2 \mathrm{O} \text { and } \\
120 \mathrm{~kg} \mathrm{P}_{2} \mathrm{O}_{5}\end{array}$ & $\begin{array}{l}100 \mathrm{~kg} \text { urea and } \\
380 \mathrm{~kg} \mathrm{~K}{ }_{2} \mathrm{O}\end{array}$ & 2 & 2 \\
\hline
\end{tabular}


TABLE II (continuation)

\begin{tabular}{|c|c|c|c|c|c|}
\hline Environments & Sowing & $\begin{array}{l}\text { Sowing fertilizing } \\
\text { (ha) }\end{array}$ & $\begin{array}{l}\text { Side dressing } \\
\text { (ha) }\end{array}$ & $\begin{array}{l}\text { Number of } \\
\text { daily } \\
\text { irrigations }\end{array}$ & $\begin{array}{l}\text { Number of } \\
\text { weedings }\end{array}$ \\
\hline AS-02 & $\mathrm{TF}$ & $\begin{array}{l}8 \mathrm{t} \text { cattle manure, } \\
450 \mathrm{~kg} \mathrm{KCl}, \\
120 \mathrm{~kg} \text { urea, } \\
450 \mathrm{~kg} \mathrm{~K}_{2} \mathrm{O} \text { and } \\
120 \mathrm{~kg} \mathrm{P}_{2} \mathrm{O}_{5}\end{array}$ & $\begin{array}{l}100 \mathrm{~kg} \text { urea and } \\
380 \mathrm{~kg} \mathrm{~K}_{2} \mathrm{O}\end{array}$ & 2 & 2 \\
\hline AR-00 & $\mathrm{TF}$ & $\begin{array}{l}12 \mathrm{t} \text { cattle manure, } \\
450 \mathrm{~kg} \mathrm{KCl}, \\
120 \mathrm{~kg} \text { urea, } \\
450 \mathrm{~kg} \mathrm{~K} 2 \mathrm{O} \text { and } \\
120 \mathrm{~kg} \mathrm{P}_{2} \mathrm{O}_{5}\end{array}$ & $\begin{array}{l}120 \mathrm{~kg} \text { urea and } \\
370 \mathrm{~kg} \mathrm{~K}_{2} \mathrm{O}\end{array}$ & 1 & 2 \\
\hline AR-01 & $\mathrm{TF}$ & $\begin{array}{l}8 \mathrm{t} \text { cattle manure, } \\
450 \mathrm{~kg} \mathrm{KCl}, \\
120 \mathrm{~kg} \text { urea, } \\
450 \mathrm{~kg} \mathrm{~K} \mathrm{O}_{2} \mathrm{O} \text { and } \\
120 \mathrm{~kg} \mathrm{P}_{2} \mathrm{O}_{5}\end{array}$ & $\begin{array}{l}120 \mathrm{~kg} \text { urea and } \\
370 \mathrm{~kg} \mathrm{~K} \mathrm{~K}_{2} \mathrm{O}\end{array}$ & 1 & 3 \\
\hline AR-02 & $\mathrm{TF}$ & $\begin{array}{l}8 \mathrm{t} \text { cattle manure, } \\
450 \mathrm{~kg} \mathrm{KCl}, \\
120 \mathrm{~kg} \text { urea, } \\
450 \mathrm{~kg} \mathrm{~K} 2 \mathrm{O} \text { and } \\
120 \mathrm{~kg} \mathrm{P}_{2} \mathrm{O}_{5}\end{array}$ & $\begin{array}{l}120 \mathrm{~kg} \text { urea and } \\
370 \mathrm{~kg} \mathrm{~K}_{2} \mathrm{O}\end{array}$ & 1 & 3 \\
\hline
\end{tabular}

${ }^{1}$ TS: Transplanting seedlings after sowing in polystyrene trays; TF: Tillage in field. (MO-00: Mossoró 2000; MO-01, Mossoró 2001; MO-02, Mossoró 2002; BA-00: Baraúna 2000; BA-01, Baraúna 2001; BA-02, Baraúna 2002; AS-00: Assu 2000; AS-01, Assu 2001; AS-02, Assu 2002; AR-00: Alto do Rodrigues 2000; AR-01, Alto do Rodrigues 2001; AR-02, Alto do Rodrigues 2002).

genotype $i$ in environment $j ; \overline{Y_{i}}=$ average of genotype $i$ in environment $k ; \overline{Y_{. j}}=$ average of environment $j$; $\overline{Y_{. .}}=$overall average of environments.

The "Stability" software (Version 3.0 Build 13) developed at the Departamento de Ciências Exatas of the Universidade Federal de Lavras was used for the estimation analyses of the stability parameters of the methods proposed by Toler and Burrows (1998) and Wricke (1965).

The described model used to explain the average response of a hybrid $i$ in an environment $j$, considering the effects of specific hybrids and environments and according to the AMMI analysis, was:

$$
y_{i j}=\mu+h_{i}+a_{j}+\sum_{k=1}^{n} \lambda_{k} \gamma_{i k}+\rho_{i j}+\varepsilon_{i j},
$$

where: $y_{i j}=$ average of hybrid $i$ in environment $j$; $\mu=$ overall average; $h_{i}$ and $a_{j}=$ effects of hybrid $i$ and environment $j$, respectively; $\lambda_{k}=$ single $k$ value of the interaction matrix $\mathrm{G} \times \mathrm{E} ; \gamma_{i k}$ and $\alpha_{j k}=$ single $k$ values corresponding to genotype $i$ and environment $j$, respectively; $\rho_{i j}=$ residual of interaction $\mathrm{G} \times \mathrm{E}, \varepsilon_{i j}=$ average experimental error, and $n=$ number of principal components kept in the model.

The selection of the AMMI model (number of axes) was based on the F test by Gollob (Gollob 1968) and Cornelius et al. (1992) at 1\% probability. All of these methods and analyses in the SAS/IML software are described in detail by Duarte and Vencovsky (1999). The coordinates of genotypes and environments on the main axes of the interaction (IPC) were represented on a double plot graph, which describes the stability and adaptability of the genotypes in the evaluation environments. 


\section{RESULTS AND DISCUSSION}

There were significant effects of the hybrids, environments and interaction among these factors for yield of fruits and soluble solids content of melon hybrids (Table III). These results indicate that the heterogeneity of the environments becomes evident, as well as the genetic variability of the genotypes studied.

The interaction between hybrids and environments indicates an inconsistent performance of the hybrids in different environments (Ramalho et al. 1993). The genotype $\times$ environment interaction for these traits was previously observed in another trials of yellow melon hybrids carried out in the municipalities of the Mossoró-Assu Agro-industrial Complex (Gurgel et al. 2005, Nunes et al. 2006), suggesting the need to evaluate the new genotypes in different environments to insure that the best ones are recommended for each particular area. In this study, there was the predominance of the complex component of interaction (Table III), which was also observed by Nunes et al. (2006).

Quantification of the simple and complex components of the interaction is important once it tells the plant breeder about the degree of difficulty to select or recommend cultivars (Vencovsky and Barriga 1992). When there is a predominance of the simple component, the researcher's job is made easier since the genotypic classification does not change. On the other hand, when the complex component is more powerful, the recommendation becomes difficult once there are genotypes that are well adapted to specific environments. Nevertheless, the plant breeder can explore the interaction genotype $x$ environment by selecting given genotypes for a given environment or region, profiting from it and, in consequence, raising the phenotypic value of the character. In the particular case of the melon grown in the MossoróAssu Agro-industrial Complex, such strategy cannot be adopted since there is little participation of the growers in the process. It must be pointed out that even when the complex component of the interaction predominates, it is possible to identify productive genotypes with wide adaptation (Vencovsky and Barriga 1992).

The most common procedures to study adaptability and stability are those using regression (Kang 1998). The method of Toler and Burrows (1998) used in this study, permits the choice of the model that best explains the phenotypic performance of a genotype, whether uni or bi-segmented. This technique also allows the genotype classification in five different groups, from A to $\mathrm{E}$, depending on the estimation for coefficients $\beta_{1 i}$ e $\beta_{2 i}$ of the model. If $\beta_{1 i}<1$ and $\beta_{2 i}>1$, the genotype is classified under group $\mathrm{A}$, whereas the genotype with $\beta_{1 i}>1$ and $\beta_{2 i}<1$ is classified under group $\mathrm{E}$.

When only one line segment is enough to explain the pattern of response of a genotype, it can be classified under group $\mathrm{B}, \mathrm{C}$ or $\mathrm{D}$ according to the estimation of common $\beta_{i}$. If the value $\beta_{i}$ is significantly higher than the unit, the genotype is grouped into B. If it is lower than the unit, then the genotype is classified under group $\mathrm{D}$. If the estimation of $\beta_{i}$ is statistically equal to the unit, the genotype falls into group $\mathrm{C}$.

Solar King and Arava were the only hybrids whose yield was explained by bi-segmented model (Table IV). Solar King and Arava were classified under groups E and A, respectively. The other hybrids followed the unisegmented model and were categorized into groups B (Supra, Num 1502), C (DRG 1537, Galileu and Solarbel) and D (GPS 400 and DRG 1531). Regarding the soluble solids content, only the Solar King followed the model with one line segment; all other hybrids followed the bi-segmented model. Solar King was classified into group B; GPS 400, DRG 1531 and DRG 1537 into group $\mathrm{A}$, whereas the others were classified into group E. The genotypes classified under group E show a high average to the traits studied in unfavorable environments and do not respond to environmental quality improvement, thus having a double undesirable performance (Toler and Burrows 1998). Unfavorable environments use low technology, less fertilizer application or no control of pests and diseases. The genotypes of group A are characterized as being able to tolerate environments that are below average in quality and responded to environmental quality improvement. The genotype with these properties is described as a material with double desirable response, and is recommended for environments that use low or high technology.

In the case of the genotypes with responses explained by only one line segment model, the interpretation of coefficient $\beta$ is commonly similar to that given by Eberhart and Russel (1966). When the esti- 
TABLE III

Analysis of the additive main effects and multiplicative interaction for yield of fruit and soluble solids content of nine hybrids of Gália melon assessed in twelve environments of the Mossoró-Assu Agro-industrial Complex.

\begin{tabular}{l|c|r|r}
\hline \multirow{2}{*}{ Sources of variation } & \multirow{2}{*}{ d.f. } & \multicolumn{2}{|c}{ Mean Square (Traits) } \\
\cline { 3 - 4 } & & \multicolumn{1}{|c}{ Yield } & Soluble solids \\
\hline Block (Environment) & 24 & $26.2050^{\mathrm{ns}}$ & $2.1973^{\mathrm{ns}}$ \\
Environment (E) & 11 & $919.6402^{* *}$ & $46.3746^{* *}$ \\
Hybrid (H) & 8 & $222.7621^{* *}$ & $7.1776^{* *}$ \\
H $\times$ E & 88 & $31.5280^{* *}$ & $4.7564^{* *}$ \\
IPCA 1 & 18 & $75.5775^{* *}$ & $16.3414^{* *}$ \\
& & $(49.03 \%)^{(1)}$ & $(70.27 \%)^{(1)}$ \\
Error(AMMI 1) & 70 & $20.2010^{\mathrm{ns}}$ & $1.7774^{\mathrm{ns}}$ \\
IPCA 2 & 16 & $34.9947^{\mathrm{ns}}$ & $2.9737^{\mathrm{ns}}$ \\
& & $(20.18 \%)^{(1)}$ & $(81.64 \%)^{(1)}$ \\
Error(AMMI 2) & 54 & $15.8177^{\mathrm{ns}}$ & $1.4230^{\mathrm{ns}}$ \\
IPCA 3 & 14 & $29.0762^{\mathrm{ns}}$ & $2.0463^{\mathrm{ns}}$ \\
& & $14.67 \% 0^{(1)}$ & $(88.49)^{(1)}$ \\
Error(AMMI 3) & 40 & $11.1772^{\mathrm{ns}}$ & $1.2048^{\mathrm{ns}}$ \\
Pool error & 192 & 20.4900 & 1.4700 \\
\hline Mean & & 27.21 & 11.34 \\
CV(\%) & & 16.65 & 10.71 \\
Simple (\%) & & 35.29 & 44.31 \\
Complex (\%) & & 64.71 & 55.69 \\
\hline
\end{tabular}

ns: No significant. $* *$ : Significant at $1 \%$ probability by the FR test (Cornelius) or F test (Snedecor). (1) Percentage of the sum of squares of genotype $\times$ environment interaction captured by the PCI (principal component of interaction). (2) Contribution of simple and complex parts of genotype $\times$ environment interaction.

mative of coefficient $\beta$ is equal to the unit, the genotypes will indeed have a wide adaptation. When it is higher than the unit, the genotypes will be specifically adapted to high quality environments and associated with high responsiveness. Finally, when the estimative of coefficient $\beta$ is lower than the unit, the genotypes will be adapted to poorer environments and associated with low responsiveness.

The DRG 1537 hybrid showed the smallest ecovalence for yield whereas Galileu, Solarbel and DRG 1537 hybrids showed the smallest ecovalence estimates for total soluble solids content (Table IV). The smaller the ecovalence is, the smaller the contribution of the genotype to the interaction and, therefore, the greater is its stability (Wricke 1965).
Another technique that has been used to study adaptability and stability is AMMI, a multivariate technique. According to this technique, the variation sources are decomposed into additive effects of genotypes and environments, and then the multiplicative effects of the interaction are studied through the principal components, thus allowing greater detailing of the sum of the interaction squares (Gauch Jr 2006).

By Gollob's criterion and that of $F_{R}$, the model selected for both characteristics was the AMMI 1 model whose residual was not significant (Table IV). In this case, it is not recommended to include the remaining axes to explain the interaction once they contain more noise than the pattern, thus making it difficult to interpret the adaptability and stability. Another result that 
TABLE IV

Estimates of the parameters of adaptability and stability of nine hybrids of Gália melon according to the method of Toler (1990) and Wricke (1965) to the characteristics of yield and soluble solids content.

\begin{tabular}{|c|c|c|c|c|c|c|c|c|}
\hline Hybrids & Means & $\beta_{1 i}$ & $\beta_{2 i}$ & $\beta_{2 i}-\beta_{1 i}$ & $\beta_{i}$ & Groups & $\mathrm{R} 2$ & $\mathrm{~W}(\%)^{1}$ \\
\hline & \multicolumn{8}{|c|}{ Yield $\left(\mathrm{t} \mathrm{ha}^{-1}\right)$} \\
\hline Arava & 30.29 & $0.87^{\mathrm{ns}}$ & $1.82 * *$ & $0.95^{*}$ & $1.39 * *$ & A & 95.15 & 18.85 \\
\hline DRG 1531 & 24.10 & $0.78^{\mathrm{ns}}$ & $0.30 * *$ & $-0.48^{\mathrm{ns}}$ & $0.53 * *$ & D & 82.27 & 14.18 \\
\hline DRG 1537 & 25.77 & $1.10^{\mathrm{ns}}$ & $0.91 * *$ & $-0.19^{\mathrm{ns}}$ & $0.99^{\mathrm{ns}}$ & $\mathrm{C}$ & 92.49 & 6.15 \\
\hline Galileu & 27.56 & $1.22^{\mathrm{ns}}$ & $0.41^{*}$ & $-0.81^{\mathrm{ns}}$ & $0.77^{\mathrm{ns}}$ & $\mathrm{C}$ & 79.22 & 12.29 \\
\hline GPS 400 & 23.72 & $0.71^{\mathrm{ns}}$ & $0.71^{\mathrm{ns}}$ & $0.01^{\mathrm{ns}}$ & $0.71 *$ & $\mathrm{D}$ & 86.80 & 9.14 \\
\hline Num 1502 & 30.12 & $0.76^{\mathrm{ns}}$ & $1.65^{* *}$ & $0.89^{\mathrm{ns}}$ & $1.26^{*}$ & B & 98.43 & 7.30 \\
\hline Solar King & 26.36 & $1.87 * *$ & $0.52^{\mathrm{ns}}$ & $-1.55^{* *}$ & $0.99^{\mathrm{ns}}$ & E & 76.64 & 11.33 \\
\hline Solarbel & 27.22 & $0.52^{\mathrm{ns}}$ & $1.37^{\mathrm{ns}}$ & $0.86^{\mathrm{ns}}$ & $0.99^{\mathrm{ns}}$ & $\mathrm{C}$ & 91.91 & 8.91 \\
\hline \multirow[t]{2}{*}{ Supra } & 29.82 & $1.88^{\mathrm{ns}}$ & $1.51^{* *}$ & $0.32^{\mathrm{ns}}$ & $1.37 * *$ & B & 96.63 & 11.86 \\
\hline & \multicolumn{8}{|c|}{ Soluble solids (\%) } \\
\hline Arava & 11.87 & $3.04 * *$ & $-0.65^{* *}$ & $-3.69 * *$ & $0.89^{* *}$ & $\mathrm{E}$ & 94.26 & 14.44 \\
\hline DRG 1531 & 10.83 & $-5.03 * *$ & $5.52 * *$ & $18.01 * *$ & $0.67 * *$ & A & 83.12 & 13.88 \\
\hline DRG 1537 & 11.05 & $-1.02 *$ & $2.00^{*}$ & $7.32 * *$ & $0.82 * *$ & A & 86.55 & 5.49 \\
\hline Galileu & 11.60 & $2.76^{* *}$ & $-0.32 * *$ & $-3.08^{* *}$ & $1.10^{* *}$ & E & 88.23 & 5.89 \\
\hline GPS 400 & 10.75 & $-5.09 * *$ & $5.64 * *$ & $18.83^{* *}$ & $0.59^{* *}$ & A & 86.85 & 15.15 \\
\hline Num 1502 & 11.87 & $2.88 * *$ & $-0.42 * *$ & $-3.30 * *$ & $0.89 * *$ & $\mathrm{E}$ & 93.01 & 20.25 \\
\hline Solar King & 11.10 & $0.47^{\mathrm{ns}}$ & $1.67^{\mathrm{ns}}$ & $12.67^{\mathrm{ns}}$ & $1.25^{* *}$ & B & 63.80 & 12.52 \\
\hline Solarbel & 11.18 & $4.75^{* *}$ & $-2.02 * *$ & $-6.75^{* *}$ & $1.14^{* *}$ & E & 83.92 & 3.46 \\
\hline Supra & 11.78 & $3.08 * *$ & $0.27^{\mathrm{ns}}$ & $-2.81 * *$ & $1.44 * *$ & $\mathrm{E}$ & 90.96 & 8.92 \\
\hline
\end{tabular}

ns: No significant. * and **: Significant at 5\% and $1 \%$ probability, respectively, by the test of $t$. 1 : ecovalence (W\%).

supports the decision to not include new axes is the interaction percentages captured by the first principal component (IPC 1) of both characteristics. For yield, IPC 1 accounted for $49.03 \%$ of the interaction, whereas for soluble solids content it accounted for $70.27 \%$. Double plot graphs will indeed be based on the average and score of the first principal component of each hybrid, as proposed by Duarte and Vencovsky (1999).

One of the advantages of the AMMI technique is the graphical representation, in which the scores of the interaction effects for each genotype and environment are plotted simultaneously. The interpretation of the graph is done by observing the magnitude and score sign of genotype and environment for the interaction axes. Under AMMI 1 model, low scores near zero are typical of genotypes and environments that contribute very little to the interaction, being considered stable
(Ferreira et al. 2006). In this study, regarding the yield and soluble solids content, although there was not much variation, DRG 1537 and Solarbel were the most stable hybrids (Figs. 1 and 2). It must be pointed out that these hybrids showed low ecovalence (Table IV), confirming their small participation in the interaction of these genotypes.

When studying stability, average is an essential parameter for the recommendation of a genotype. According to the growers, to make a profit the melon yield must exceed $25 \mathrm{t} \mathrm{ha}^{-1}$. Taking into account this minimum threshold, it is worth to say that the hybrids GPS 400 and DRG 1531 did not reach the minimum threshold. Supra, Num 1502 and Arava had the highest yield (Fig. 1).

As for the soluble solids content, foreign sales require values between 12 and $14 \%$. However, fruits 


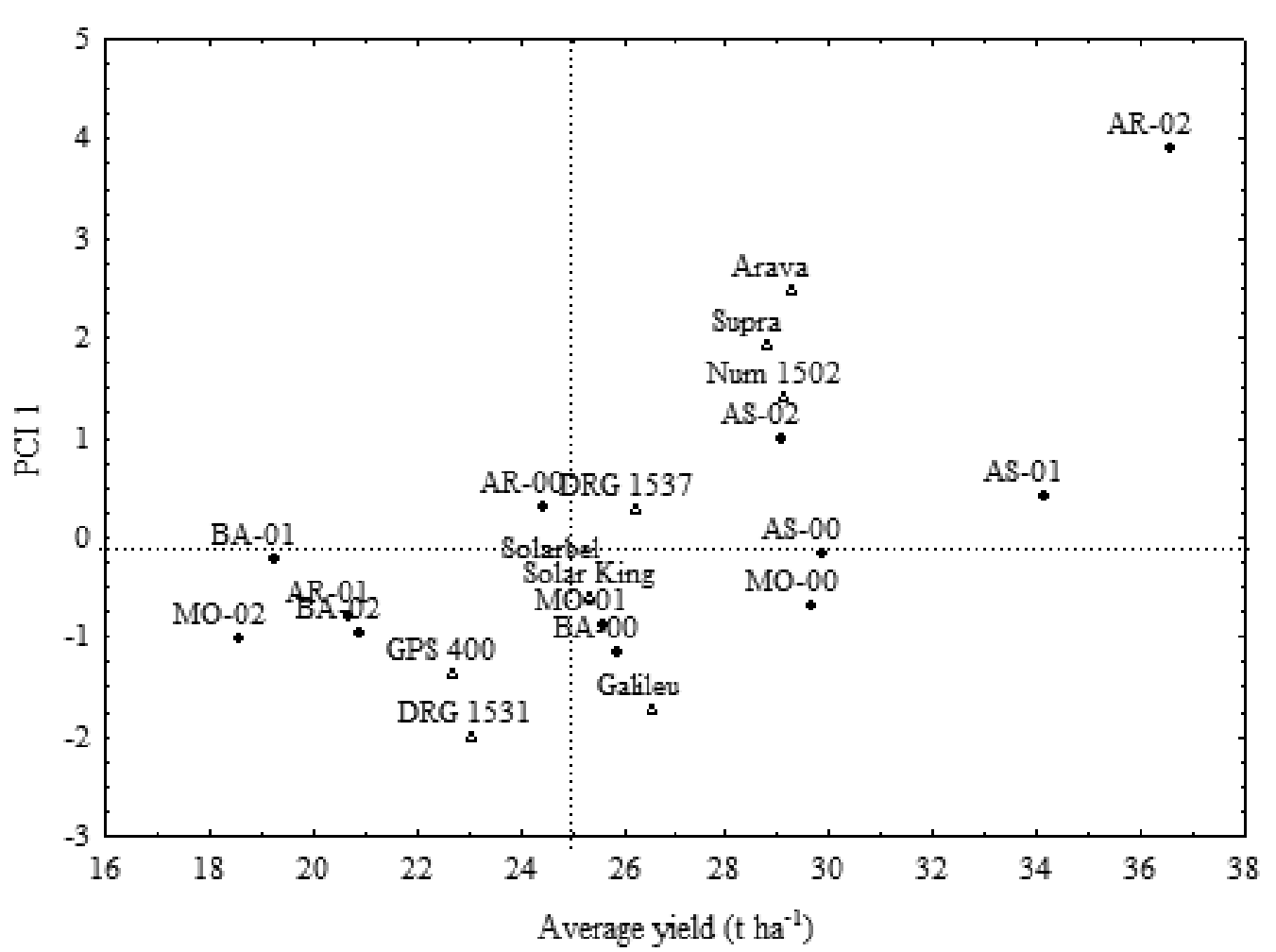

Fig. 1 - Biplot AMMI1: first principal component (PCI 1) $\times$ average yield of nine hybrids $(\Delta)$ from melon Gália evaluated in twelve environments (•) of the Mossoró-Assu Agro-industrial Complex (MO-00: Mossoró, 2000; MO-01: Mossoró, 2001; MO-02: Mossoró, 2002; BA-00: Baraúna, 2000; BA-01: Baraúna, 2001; BA-02: Baraúna, 2002; AS-00: Assu, 2000; AS-01: Assu, 2001; AS-02: Assu, 2002; AR-00: Alto do Rodrigues, 2000; AR-01: Alto do Rodrigues, 2001; AR-02: Alto do Rodrigues, 2002).

with values between 10 and $13 \%$ have been sold at the Natal harbor, Rio Grande do Norte, Brazil (Sales Júnior et al. 2006). This situation proves to be favorable to the growers since the average soluble solids content of these hybrids were within the commercial range.

Among the evaluated hybrids, DRG 1537 was the most stable in terms of yield and adaptation according to the three mathematical methods used in this study. The soluble solids content of DRG 1537 was considered stable under AMMI and ecovalence methods, but was responsive to solids content according to Toler and Burrows's method (Toler and Burrows 1998). In addition, its average yield was higher than $25 \mathrm{tha}^{-1}$, and its soluble solids content higher than $11.05 \%$. It would be the most recommended hybrid for the studied region.

The AMMI analysis also allows a study of the contribution of environments to the interaction and helps to select evaluation locations. A greater variation in the hybrids yield was observed in the environments BA-01
(Baraúna 2001), AR-00 (Alto do Rodrigues 2000) and AS-00 (Assu 2000). With lower IPC 1 values, these are considered the most stable environments, whereas AR-02 (Alto do Rodrigues 2002) was the most unstable environment (Fig. 1). In general, considering the amplitude and magnitude of the scores for the three years, the most stable locations were Mossoró, Assu and Baraúna. Alto do Rodrigues was the most unstable location. Assu was the location that showed the highest yield for the three-year average (Fig. 1).

The variation of the scores of soluble solids contents was smaller than the variation for yield (Figs. 1 and 2, Table V). MO-00 (Mossoró 2000), MO-02 (Mossoró 2002), BA-00 (Baraúna 2000), AS-01 (Assu 2001), AR-01 (Alto do Rodrigues 2001) and AR-02 (Alto do Rodrigues 2002) were the most stable environments for soluble solids contents, whereas BA-01 (Baraúna 2001) and BA-02 (Baraúna 2002) were the most unstable (Fig. 2). Mossoró, Assu and Alto do 


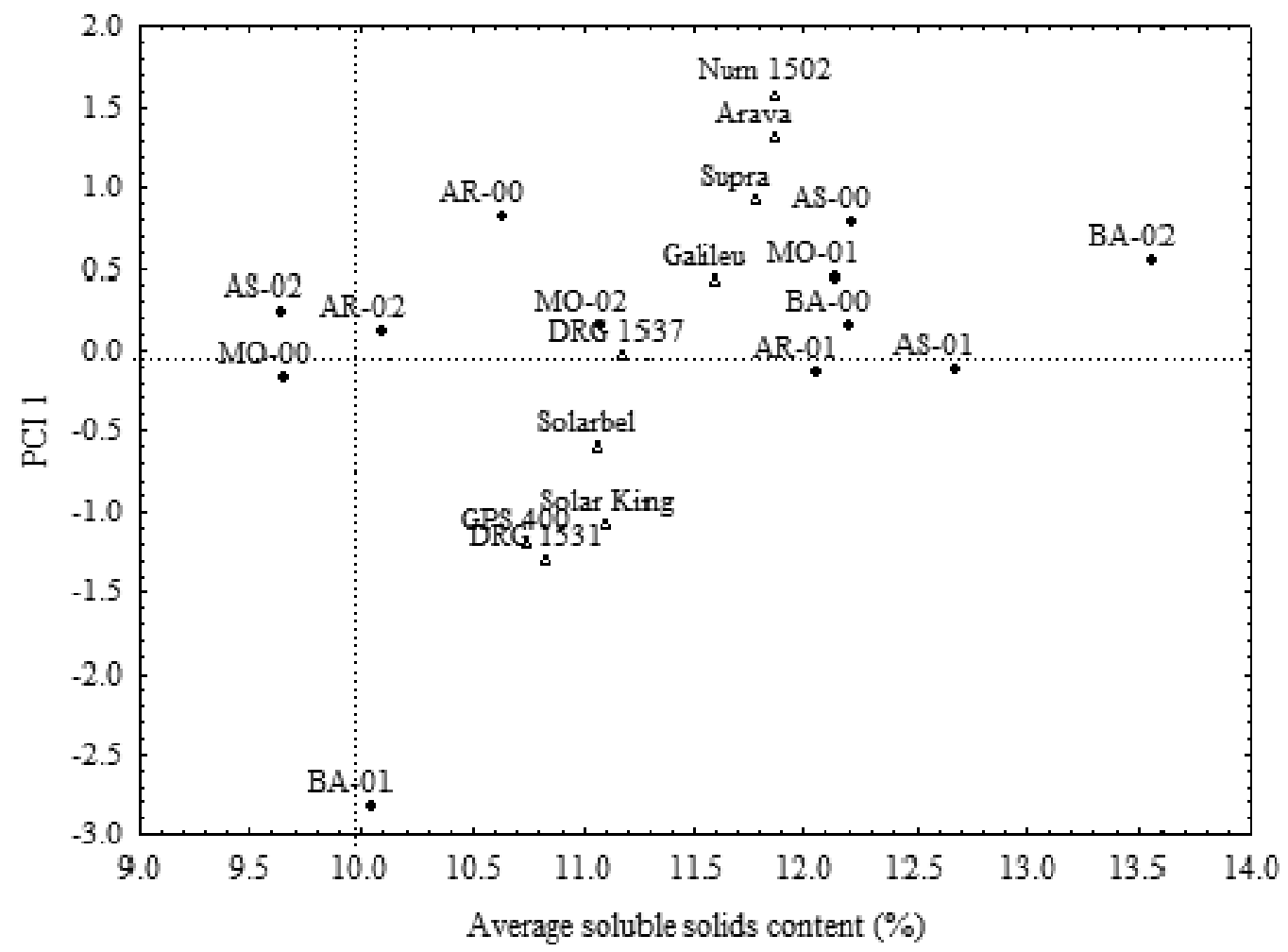

Fig. 2 - Biplot AMMI1: first principal component (PCI 1) $\times$ average of soluble solids content of nine hybrids $(\Delta)$ from melon Gália evaluated in twelve environments (•) of the Mossoró-Assu Agro-industrial Complex (MO-00: Mossoró, 2000; MO-01: Mossoró, 2001; MO-02: Mossoró, 2002; BA-00: Baraúna, 2000; BA-01: Baraúna, 2001; BA-02: Baraúna, 2002; AS-00: Assu, 2000; AS-01: Assu, 2001; AS-02: Assu, 2002; AR-00: Alto do Rodrigues, 2000; AR-01: Alto do Rodrigues, 2001; AR-02: Alto do Rodrigues, 2002).

Rodrigues were more stable in comparison to Baraúna, which was the most stable location. The environmental stability tells us about the reliability of the genotype sequencing in a given evaluation location regarding the classification for the average of the tested environments (Oliveira et al. 2003). Therefore, considering yield and soluble solids content as well, the most suitable locations to test melon hybrids were Assu and Mossoró. In these two locations, the hybrid classification should show less discrepancy in comparison to the overall average, thus yielding a more reliable sequencing for the purposes of recommendation.

\section{CONCLUSIONS}

The complex component accounts for most of the interaction hybrid $\times$ environment for yield and soluble solids contents of melon hybrids. The hybrid DRG 1537 was the most stable, productive, and presented the highest soluble solids contents. For these reasons, it is the most promising hybrid to be grown in the Mossoró-Assu Agro-industrial Complex.

\section{RESUMO}

Os objetivos deste estudo foram determinar a importância das componentes simples e complexa da interação genótipo $\times$ ambiente e avaliar a adaptabilidade e estabilidade de híbridos de melão Gália. Nove híbridos foram testados em doze ambientes do Estado do Rio Grande Norte no período de 2000 a 2001. Os experimentos foram conduzidos em blocos completos casualizados com três repetições. Os métodos estatísticos de Toler e Burrows, Wricke e AMMI (Additive Main effect and Multiplicative Interaction) foram usados para estudar a adaptabilidade e estabilidade. A componente complexa é responsável pela maior parte da interação genótipo $\times$ ambiente para a produtividade e teor de sólidos solúveis dos frutos. Os ambientes associados com Mossoró e Assu são os mais adequados para a avaliação de melão híbrido. O híbrido DRG 1537 é o mais promissor para o cultivo no Complexo Agro- 
TABLE V

Predicted means of yield and soluble solids content of fruits by additive main effects and multiplicative interaction with only the first principal component of interaction (AMMI 1) of nine Gália melon hybrids evaluated in twelve environments of the Mossoró-Assu Agro-industrial Complex.

\begin{tabular}{|c|c|c|c|c|c|c|c|c|c|c|}
\hline \multirow[b]{2}{*}{ Environments } & \multicolumn{10}{|c|}{ Hybrids } \\
\hline & Arava & $\begin{array}{c}\text { DRG } \\
1531\end{array}$ & $\begin{array}{l}\text { DRG } \\
1537\end{array}$ & Galileu & $\begin{array}{c}\text { GPS } \\
400\end{array}$ & $\begin{array}{l}\text { Num } \\
1502\end{array}$ & $\begin{array}{l}\text { Solar } \\
\text { King }\end{array}$ & Solarbel & Supra & Means \\
\hline & \multicolumn{10}{|c|}{ Yield $\left(\mathrm{t} \mathrm{ha}^{-1}\right)$} \\
\hline MO-00(1) & 32.05 & 28.97 & 29.49 & 32.24 & 28.14 & 32.62 & 30.25 & 30.51 & 31.97 & 30.69 \\
\hline MO-01 & 28.48 & 24.42 & 25.30 & 27.75 & 23.73 & 28.82 & 26.00 & 26.45 & 28.28 & 26.58 \\
\hline MO-02 & 20.12 & 18.56 & 18.51 & 21.74 & 17.51 & 21.05 & 19.35 & 19.32 & 20.23 & 19.60 \\
\hline BA-00 & 27.11 & 26.07 & 25.83 & 29.22 & 24.95 & 28.17 & 26.70 & 26.56 & 27.29 & 26.88 \\
\hline BA-01 & 22.82 & 17.61 & 18.92 & 21.01 & 17.09 & 22.89 & 19.56 & 20.23 & 22.47 & 20.29 \\
\hline BA-02 & 22.38 & 20.53 & 20.59 & 23.72 & 19.52 & 23.24 & 21.42 & 21.44 & 22.46 & 21.70 \\
\hline AS-00 & 33.56 & 28.07 & 29.49 & 31.48 & 27.59 & 33.57 & 30.11 & 30.84 & 33.18 & 30.88 \\
\hline AS-01 & 39.26 & 31.22 & 33.58 & 34.78 & 31.11 & 38.66 & 34.06 & 35.29 & 38.56 & 35.17 \\
\hline AS-02 & 35.61 & 24.97 & 28.3 & 28.70 & 25.25 & 34.39 & 28.64 & 30.37 & 34.59 & 30.09 \\
\hline AR-00 & 29.29 & 21.72 & 23.91 & 25.26 & 21.55 & 28.80 & 24.42 & 25.55 & 28.65 & 25.46 \\
\hline AR-01 & 22.50 & 20.44 & 20.58 & 23.65 & 19.47 & 23.32 & 21.40 & 21.46 & 22.55 & 21.71 \\
\hline AR-02 & 50.26 & 26.61 & 34.78 & 31.12 & 28.78 & 45.97 & 34.39 & 38.66 & 47.61 & 37.57 \\
\hline \multirow[t]{2}{*}{ Means } & 30.28 & 24.1 & 25.77 & 27.56 & 23.72 & 30.12 & 26.36 & 27.22 & 29.82 & 27.22 \\
\hline & \multicolumn{10}{|c|}{ Soluble solids $(\%)$} \\
\hline MO-00 & 9.97 & 9.38 & 9.48 & 9.86 & 9.28 & 9.93 & 9.62 & 9.51 & 9.94 & 9.66 \\
\hline MO-01 & 13.24 & 11.06 & 11.58 & 12.59 & 11.02 & 13.36 & 11.43 & 11.96 & 12.98 & 12.14 \\
\hline MO-02 & 11.81 & 10.37 & 10.69 & 11.41 & 10.30 & 11.86 & 10.68 & 10.92 & 11.66 & 11.08 \\
\hline BA- 00 & 12.95 & 11.49 & 11.82 & 12.54 & 11.42 & 12.99 & 11.80 & 12.05 & 12.79 & 12.21 \\
\hline BA-01 & 6.85 & 13.21 & 11.48 & 9.11 & 12.83 & 6.16 & 12.88 & 10.01 & 7.90 & 10.05 \\
\hline BA-02 & 14.81 & 12.36 & 12.95 & 14.07 & 12.33 & 14.95 & 12.74 & 13.39 & 14.50 & 13.57 \\
\hline AS-00 & 13.78 & 10.70 & 11.45 & 12.82 & 10.70 & 13.97 & 11.14 & 12.03 & 13.37 & 12.22 \\
\hline AS-01 & 13.06 & 12.33 & 12.47 & 12.90 & 12.24 & 13.03 & 12.58 & 12.54 & 13.02 & 12.68 \\
\hline AS-02 & 10.50 & 8.84 & 9.22 & 10.02 & 8.78 & 10.56 & 9.16 & 9.49 & 10.31 & 9.65 \\
\hline AR-00 & 12.24 & 9.05 & 9.84 & 11.25 & 9.06 & 12.45 & 9.50 & 10.44 & 11.82 & 10.63 \\
\hline AR-01 & 12.41 & 11.74 & 11.86 & 12.27 & 11.64 & 12.38 & 11.98 & 11.91 & 12.38 & 12.06 \\
\hline AR-02 & 10.78 & 9.45 & 9.74 & 10.42 & 9.38 & 10.81 & 9.75 & 9.94 & 10.64 & 10.10 \\
\hline Means & 11.87 & 10.83 & 11.05 & 11.60 & 10.75 & 11.87 & 11.10 & 11.18 & 11.78 & 11.34 \\
\hline
\end{tabular}

(1) (MO-00: Mossoró 2000; MO-01, Mossoró 2001; MO-02, Mossoró 2002; BA-00: Baraúna 2000; BA-01, Baraúna 2001; BA-02, Baraúna 2002; AS-00: Assu 2000; AS-01, Assu 2001; AS-02, Assu 2002; AR-00: Alto do Rodrigues 2000; AR-01, Alto do Rodrigues 2001; AR-02, Alto do Rodrigues 2002). 
industrial Mossoró-Assu, devido à sua estabilidade, alta produtividade e alto teor de sólidos solúveis.

Palavras-chave: Cucumis melo, interação genótipo $\times$ ambiente, análise AMMI, protocolo de agrupamento não-linear, híbridos.

\section{REFERENCES}

Cornelius PL, Seyedsadr M and Crossa J. 1992. Using the shifted multiplicative model to search for "separability" in crop cultivar trials. Theor Appl Genet 84: 161-172.

CRUZ CD. 2001. Programa Genes: Aplicativo computacional em Genética e Estatística, Viçosa: UFV, 442 p.

CRUz CD And CAstoldi FL. 1991. Decomposição da interação genótipos $\times$ ambientes em partes simples e complexa. Rev Ceres 38: 422-430.

Cruz CD AND Regazzi AJ. 1994. Modelos biométricos aplicados ao melhoramento genético. Viçosa: UFV, 390 p.

Cruz CD, TORRES RA AND VENCOVSKY R. 1989. An alternative approach to the stability analysis proposed by Silva and Barreto. Rev Bras Genet 12: 567-580.

DUARTE JB AND VEnCOVSKY R. 1999. Interação Genótipos $\times$ Ambientes: uma introdução à análise AMMI. Ribeirão Preto, BR: Sociedade Brasileira de Genética 1: 60 .

EBERHART SA AND RUSSEL WA. 1966. Stability parameters for comparing varieties. Crop Sci 6: 36-40.

FAN XM, Kang MS, Chen H, Zhang Y, TAN J AND XU C. 2007. Yield stability of maize hybrids evaluated in multi-environment trials in Yunnan, China. Agron J 99: $220-228$.

Ferreira DF, Demetrio CGB, Manly BFJ, Machado AA AND VENCOVSCK R. 2006. Statistical models in agriculture: biometrical methods for evaluating phenotypic stability in plant breeding. Cerne 12: 373-388.

FINLAY KW AND WILKINSON GN. 1963. The analysis of adaptation in a plant - breeding programme. Aust J Agric Res 14: 742-754.

FNP. 2008. Agrianual: Anuário da agricultura brasileira. São Paulo: Instituto FNP, 502 p.

GABRIEL KR. 1971. The biplot graphic display of matrices with application to principal component analysis. Biometrika 44: 453-467.

GAUCH JR HG. 2006. Statistical analysis of yield trials by AMMI and GGE. Crop Sci 46: 1488-1500.

GolLob HF. 1968. A statistical model which combines features of factor analytic and analysis of variance techniques. Psychom 33: 73-145.
Gurgel FL, Krause W, SChmildt ER and Sena LCN. 2005. Indicação de híbridos de melão para o Rio Grande do Norte. Rev Ceres 52: 115-123.

KANG SK. 1998. Using genotype-by-environment interaction for crop cultivar development. Adv Agron 62: 199252.

KARCHI Z. 2000. Development of melon culture and breeding in Israel. Proceedings of $7^{\text {th }}$ EUCARPIA Meeting on Cucurbit Genetics and Breeding. Acta Hortic 510: $13-17$.

Morais LK, Moura MF, Vencovsky R AND PinheIRO JB. 2008. Adaptabilidade e estabilidade fenotípica em soja avaliada pelo método de Toler. Bragantia 67: $275-284$

Nunes GHS, Madeiros AES, Grangeiro LC, SAntos GM AND SALES JÚNIOR R. 2006. Estabilidade fenotípica de híbridos de melão amarelo avaliados no Pólo Agroindustrial Mossoró-Assu. Pesq Agropec Bras 41: $57-67$.

Nunes GHS, RESENDE GDSP, RAMALho MAP AND SANTOS JB. 2002. Implicações da interação genótipos $\times$ ambientes na seleção de clones de eucalipto. Cerne 8 : $49-58$.

Nunes GHS, Santos Júnior JJ, Andrade FV, Bezerra Neto F, Menezes JB and Pereira EWL. 2005. Desempenho de híbridos do grupo inodorus em Mossoró. Hortic Bras 23: 90-94.

Nunes GHS, Santos Júnior JJS, Vale FA, Bezerra Neto F, Almeida AHB And Medeiros DC. 2004. Aspectos produtivos e de qualidade de híbridos de melão cultivados no agropolo Mossoró-Assu. Hortic Bras 22: 744-747.

Oliveira AB, DuARTe JB AND PINHEIRo JB. 2003. Emprego da análise AMMI na avaliação da estabilidade produtiva em soja. Pesq Agropec Bras 38: 357-364.

Ramalho MAP, SANTOS JB AND ZimMERmanN MJ. 1993. Genética Quantitativa em plantas autógamas. Goiânia: UFG, 272 p.

REZENDE MDV. 2002. Genética biométrica e estatística no melhoramento de plantas perenes. Brasília: Embrapa Informação tecnológica, 975 p.

Rosse LN AND Vencovsky R. 2000. Modelo de regressão não-linear aplicado ao estudo da estabilidade fenotípica de genótipos de feijão no Estado do Paraná. Bragantia 59: 99-107.

Rosse LN, Vencovsky R And Furtado DF. 2002. Comparação de métodos de regressão para avaliar a estabilidade fenotípica em cana-de-açúcar. Pesq Agropec Bras 37: 25-32. 
SAlEs JÚNior R, DANTAS F, SALVIANo AM AND Nunes GHS. 2006. Qualidade do melão exportado pelo porto de Natal-RN. Cienc Rural 36: 286-289.

Silva JGC AND BARRETo JN. 1985. Aplicação da regressão linear segmentada em estudos da interação genótipo $\times$ ambiente. In: Simpósio de Experimentação Agrícola, 1, Piracicaba. Resumos. Campinas, Fundação Cargill, p. 49-50.

TOLER JE AND BurRows PM. 1998. Genotypic performance over environmental arrays: a non-linear grouping protocol. J Appl Stat 25: 131-143.
VENCOVSKY R AND BARRIGA P. 1992. Genética biométrica no fitomelhoramento. Ribeirão Preto-SP: Sociedade Brasileira de Genética, 486 p.

Verma MM, Chahal CS And Murty BR. 1978. Limitations of conventional regression analysis: a proposed modification. Theor Appl Gen 53: 89-91.

WRICKE G. 1965. Zur berechnung der okovalenz bei sommerweizen und hafer. Pflanzenzuchtung 52: 127-138. 